\title{
Spatial Potential of Middle-Sized Towns in Slovakia: Lost Spaces of Humenné, Levice and Topol'čany
}

AUTHORS:

\section{Romana Hajduková ${ }^{\star *}$}

Alžbeta Sopirová ${ }^{2}$

1,2 Slovak University of Technology in Bratislava, Faculty of Architecture and Design, Institute of Urban Design and Planning, Slovakia

\section{*CORRESPONDING AUTHOR \\ E-mail: romana.hajdukova@stuba.sk}

ARTICLE INFO

Sent: Mar 31, 2021

Accepted: Apr 22, 2021

\begin{abstract}
Under the pressure from investors, Slovakia has experienced significant urban sprawl into the countryside in the last three decades. This development resulted in the loss of agricultural land, despite the fact that towns and cities in the built-up area have great potential in the vacant land lots. It is crucial to identify the lost spaces and incorporate them in the regeneration of urban structure and green infrastructure of Slovak towns and cities. The paper presents the results of the case study of lost spaces in Slovak towns that aimed to confirm the hypotheses: "Can the intensification on lost spaces within the build-up area be a better alternative than the current urban sprawl into the countryside?" and "Is it true that most lost spaces are located in the centre of towns?" The research focuses on examining the lost spaces suitable for new development and the spatial potential of the built-up urban area in three towns - Humenné, Levice, and Topol'čany. The lost spaces examined in this study are: urban fallows, vacant lots, residential green space, green space connected to public amenities and green space connected to industrial zones. The study aims to determine the area of lost spaces compared to development sites in the suburbs and to confirm the hypothesis that the intensification of urban structure is a viable alternative to the urban sprawl into the countryside. The conclusion inferred from the research has brought interesting findings and useful information for further investigation. It is crucial to find the optimum ratio between the intensification of urban structure on the land of lost spaces and leaving some space free to become a part of the blue-green infrastructure of a town, which is specific to each city. The objective of the paper is to draw attention to the potential of lost spaces as prospective areas for intensification of the urban structure of Slovak towns.
\end{abstract}

\section{KEYWORDS:}

town, intensification, lost space, development sites, urban revitalization

\section{INTRODUCTION}

The biggest challenge of urban planners is to tackle climate change and to apply the principles of sustainability in urban planning. This is mostly related to the concepts of compact city and inner urban development which aim to maintain the boundaries of built-up areas and to develop towns and cities in their built-up areas. After 1989, urban planning in Slovakia has been affected by significant urban sprawl into the city suburbs. The expansion has manifested in the mono-functional areas of individual residential housing, industrial zones, and commercial centres characterized by low-density and high demands on transport and technical infrastructure. New development projects have been built at the expense of often very fertile agricultural land.

Nowadays, the urban fabric of even small towns has been disintegrated and disrupted, with pedestrian networks that have become disjointed and disorientating. The dependence on automobiles is not a luxury, but a necessity. Public spaces are neglected, and inhabitants are unable to establish a relationship with their towns. The identification of gaps in urban structure and the filling of the gaps in its completion are supposed to assist in bringing back continuity and bringing the inhabitants back to the city.

Therefore, urban planners ponder such questions as: "Can the intensification on lost spaces within the built-up area be a better alternative than the current urban sprawl into the countryside?" and "Is it true that most lost spaces are located in the centre of towns and cities?"

\section{THEORETICAL FRAMEWORK}

In the second half of the $20^{\text {th }}$ century, efforts to increase land cost and urban structure density had a negative impact on public space quality. In her book The Death and Life of Great American Cities, Jane Jacobs [1] wrote about the importance of 
building compact cities with mixed-use and short distances. On the contrary, in his book Triumph of the City, urban economist Edward Glaeser [2] argues that expansive city growth in suburban areas is a sign of a successful and prosperous city. Glaeser considers cities to be our greatest invention, hope and future and praises them for the ability to constantly deal with and solve their issues. Both opinions are true, though it is essential to find the optimum rate of intensification and expansion of urban structure, which may vary, as it is specific to each town or city.

\section{Lost spaces defined}

With regard to inner-city development, it is necessary to identify areas within the built-up area that are suitable for further development. We are frequently confronted with examples of brownfield regeneration or remediation and subsequent construction on vacant lots. How do we develop a city without brownfields suitable for redevelopment? The answer may be provided by lost spaces mentioned by landscape architect Roger Trancik [3]. Lost spaces are residual areas between city districts on the outskirts of towns and cities, with unstructured landscapes surrounding solitary buildings, which are the outcome of nonconceptual design (inappropriate scale, situation on the plot or functional use) as well as any abandoned, neglected and dilapidated "anti-spaces" just "begging" for regeneration. They are often buffer zones, non-functional buildings in industrial areas, and shopping centres with empty spaces for which there is no longer enough purchasing power in declining towns. They include landscapes of housing estates, the transport protection zones of highways, railways, and roundabouts or buffer zones where different forms of mono-functional and inconsistent use meet and clash. These spaces are a result of shortcomings in urban designs, remnants for which no use has been found and which were never redeveloped, for a multitude of reasons.

In Open Space: Freedom and Control, Kevin Lynch and Stephen Carr [4] discuss the wastelands as places on the margins, out of sight and out of mind: "the vacant lots, back alleys, dumps, and abandoned places rights-of-way." The young generation could unleash their creativity in these places. The more space opens up to new activities, the greater freedom they offer. The French term "terrain vague" is used to describe lost spaces, predominantly reclaimed by nature with ruins of buildings visible through overgrown trees and shrubbery. The term was used by architect Ignasi de Solà-Morales [5] in an essay in which he described them as empty, abandoned spaces with marks of the past that a photographer's eye might find captivating. In her book by the same name, Non-places of cities, architect and urban planner A. B. Háblová [6] divides the non-places into lost spaces, landfills, transit, temporary and virtual spaces. They also include non-reclaimed landfills overgrown by the city, transit areas, and refugee camps with a strong sense of temporality. The author identifies the feeling of being lost in space with genius loci. Neglected places are often the result of the absence of genius loci, which implies an absence of a relationship between inhabitants and the urban spaces. Seeing the same spaces every day dulls our senses and we lose our sense of perception of beauty and ugliness [7]. On the other hand, ethnologist and anthropologist Marc Augé [8] uses the term non-places (with a dash) to describe transit places where people only pass by without forming any relationship to such places.

In scholarly literature, there are also other terms used for lost spaces. One of them is "voids" describing car parks and buffer zones near traffic routes [9]. Doron [10] mentions white areas, dead zones, and the so-called SLOAPs (Space Left Over After Planning) - spaces remaining after planning. Larsen [11] includes in the term "vague spaces" everything non-functional, such as empty spaces, indeterminate spaces, fallow lands and many more.

\section{How do lost spaces come into existence?}

The lost spaces emerged in European and American cities in the 1950s and 1960s. The reasons were the growing dependence on automobiles, open spaces designed by architects of the modern movement, urban planning policies of dividing cities into functional zones, the reluctance of municipal authorities to assume responsibility for public spaces, and closing down of many industrial parks and barracks [3].

The city reconstruction in Slovakia during the socialist era consisted mainly in the demolition of old townhouses and building of modern architecture without any thought-out urban concepts. There were shopping malls located in "solitary" buildings, standardized "pavilion plan" hospitals and schools, and lowdensity housing estates surrounded by unused landscapes. Such buildings do not communicate with public space. The Athens Charter of 1933 introduced functional zoning in cities based on the modern architecture paradigm. Walking distances were lengthened even in smaller towns, where walking was sometimes no longer feasible and an increase in the speed of transport was required. Cars became more affordable and the demand for parking capacities greatly increased. Residential green spaces and vacant land lots in cities began to give way to parking lots. After the fall of the regime, social and economic changes initiated the transition from planned to market economy. Privatization of companies resulted in the closing down or reduction of production within a decade. Industrial companies then were attempting to "go big" with a focus on one field of industry which caused their decline. All the abandoned areas and buildings were left to decay. On the contrary, in her book The Economy of Cities, Jane Jacobs [12] claims that smaller companies are better able to respond fast to the rapidly changing market needs.

Urban transformation and reconstruction of cities is an unfinished, ongoing creative process of constant evaluation of urban structure [13]. There is ceaseless suburbanization of individual residential housing as well as a transformation of industrial areas. However, this development is characterised by lowdensity, which conflicts with the required intensification of urban structure in the cities [14].

\section{Potential of lost spaces}

On the one hand, lost spaces are a problem for cities, but on the other hand, there is the potential for further development. 
They are places of numerous creative projects initiated by municipal authorities, investors, and residents. In this way, they can be involved in the revitalization of the environment closest to them. Examples of such revitalization do not necessarily have to be new constructions filling the gaps and creating a homogenous urban structure. Vacant land can be used to improve public spaces, for example by means of guerrilla gardening [15] which means cultivation of uncultivated land without owners' permission [6]. It does not have to be in the form of community gardens in gaps of the city blocks, but in the form of front gardens and flower planting on green traffic strips instead. Larger unbuildable land plots can become city parks or free multifunctional areas for Saturday marketplaces, occasional cultural events, a winter ice rink, or a parking lot for weekend use.

The importance of the lost spaces in current city development was predicted by Roger Trancik [16] almost 40 years ago in his book Finding Lost Space, where he presented a vision of the year 2000. He deemed the redevelopment of lost spaces and how we would cope with this potential to be the main problem for the next generation of urban planners. Considering vacant land lots in cities we would find enough room for the city development for next 20 to 30 years. The use of lost spaces also has its pitfalls to consider. "Back-to-the-city-movement" [17] has become a trend across borders, transforming the inner city into a condo city. Public amenities are pushed into wider city centres, which is in contradiction with the compact city concept. Urban planners should focus on finding an optimum rate between intensification of urban structure and open space while ensuring mixed-use within the city blocks.

\section{METHODS}

The objective of the study is to evaluate the spatial potential of inner town and to determine the extent of buildable lost spaces within the built-up areas and compare it to development outside built-up areas as proposed in master plans. Hypothesis and analyses are applied in a case study of three medium-sized Slovak towns with a population of 20,001 to 35,000 [18]. Humenné, Levice, and Topol'čany have undergone a major reconstruction and development of industrial areas which currently either do not reach the production capacity from the period of the biggest production or have been transformed to be used for another purpose. Another decisive factor for choosing these towns was the availability of master plans. The towns are located in eastern and western Slovakia. Their demography can be characterized by slow decline and aging of the population. (Tab. 1)

Table 1: Graph of population decline in selected towns for years 2000 - 2020. Author: Romana Hajduková Data source: Application DATACUBE ŠU SR (1 March 2021) available at: http://datacube.statistics.sk/\#!/view/sk/VBD_DEM/om7101rr/v_om7101rr_00_00_00_sk

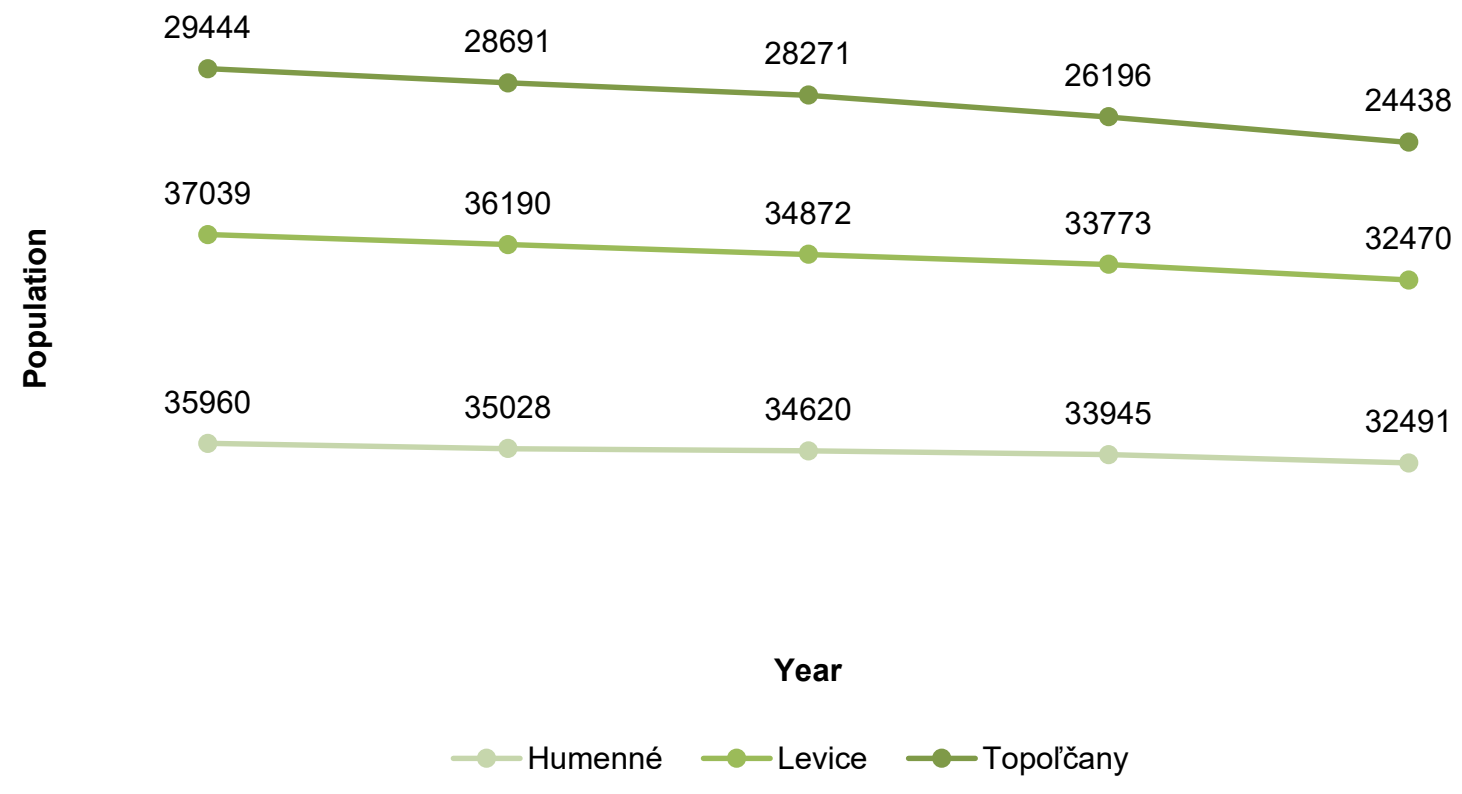

The presented study uses spatial analysis of selected towns and quantitative data obtained from analyses. The identification of lost spaces was conducted on the background of an orthophoto map and cadastral maps available through the free map services (OCG) of the Geoportal GKÚ [19]. The freeware program QGIS was used for spatial analysis, and identified areas were drawn using shapefile layers with assigned qualitative and quantitative data in attribute tables. Data from attribute tables were analysed in Microsoft Excel using Pivot Tables. The outcome of the analyses was presented in schemes and tables.

\section{Terminology of lost spaces}

For spatial analysis and identification of lost spaces, it is necessary to define basic terms frequently used in the study. The first term is the built-up area boundary (as of 1 January 1990) 
redrawn from the free cadastral map (WMS) of the Geoportal GKÚ. This boundary is currently often out of date, so actual built-up area boundary was used to supplement the information. It was identified on the background of the orthophoto map and cadastral map (both available from the GKÚ). Areas previously developed in the suburbs were drawn (as of 1 January 2021). The size of built-up area means its area in hectares and the size of actual built-up area means the sum of all built-up areas identified within the analysis.

The location of lost spaces within the towns has been determined in three basic urban zones: the town centre, the inner town, and the suburbs. The town centres are historical cores with pedestrian zones, cultural facilities and municipal and administrative buildings, near the original settlement site. Good accessibility has made these areas into a hub used for residential, commercial, and business purposes. The inner city closely surrounds the city core and is defined by the inner boundary - a boundary of the city core and the outer boundary - a line between compact urban structure and residential family housing area. The most typical feature is the mixed use combining housing estates, public amenities, industrial estates, etc. The traffic is most dense there, with the biggest concentration of parking lots. [20] The suburbs (or suburban areas) are areas beyond the outer boundary of the inner city, defined as residential family housing areas with rural character or mixed-use areas combining residential, commercial, and other uses. [21]

Lost spaces include a wide range of diverse types of spaces, some of them thought to be unbuildable. In this study, we have focused on buildable lost spaces ideal for the intensification of urban structure.

(Buildable) urban fallows are often green spaces with or without overgrown trees and shrubbery with no buildings on the site. In this study, fallows have the minimal area of $400 \mathrm{~m}^{2}$. Vacant lots are any vacant lots in the continuous urban structure of the residential housing area. Extra-large lots have also been included, which were categorized according to the size of surrounding lots and the requirement that no buildings would be on such land lots. Some areas with single-family dwellings were lined by wide strips of uncultivated greenery. Those meeting the required dimensions for family house construction were thus marked as vacant lots. Unused landscape surrounding solitary buildings is often in a special category. Residential green spaces without complementing urban furniture or playgrounds are relevant for urban structure intensification. This type includes larger green areas $\left(1,600 \mathrm{~m}^{2}\right.$ at minimum), such as unused courtyards, wide strips separating apartment buildings from roads (width $20-40 \mathrm{~m}$ ), and buffer zones on housing site margins. Green spaces around public amenities are similar and they often only fill the gaps on the site margins, especially near solitary buildings. We have also included green spaces surrounding school and hospital buildings, shopping malls, and sport grounds here. The minimum area was set at $100 \mathrm{~m}^{2}$, as it can be used for the construction of small and temporary buildings. Industrial estate green spaces ideal for further construction are often abandoned, just filling gaps between buildings and serving as a buffer zone on the site margins. No minimum area limit has been set there.

Furthermore, we will analyse the size and function of development sites, often adjacent to existing built-up areas, in masterplans. In case of development sites, we will focus on those sites which were approved by the municipal authorities in masterplans and updates of masterplans. Sites where construction has taken place are not included here. Prospective sites of masterplans were also not included in the aforementioned type.

\section{RESEARCH}

As many other Slovak towns, Humenné, Levice, and Topol'čany have undergone the biggest urban, economic, and demographic growth after World War II. New job opportunities in state companies supported the new development of housing estates and public amenities in the towns and cities. Today's city form was built mainly between the $50 \mathrm{~s}$ and 80 s of the $20^{\text {th }}$ century. The lost spaces identified in the study are the outcome of inconsistent spatial planning and modern movement in urban design and architecture.

\section{Humenné}

The continuity of the urban structure of Humenné has been disrupted, particularly by railway tracks dividing the town and the square into two parts. The square with Humenné castle lies in the north, surrounded by block structure and adjacent industrial area and suburbs. In the south, there are the housing estates built in the 1970s and 1990s and an industrial zone surrounding the extension added to the square. (Fig. 1)

The first analysed category is urban fallows. Based on the location within the town we can say that urban fallows are evenly spaced in urban zones, but the largest fallows lie in the suburbs. This is due to the built-up boundary including arable land in the urban area. They are currently classified as development sites in the masterplan. Vacant lots are mostly located in the suburbs, since there are no large residential housing areas in the inner town. Together, these places constitute $8.01 \%$ of the size of the actual built-up area, of which $6.36 \%$ are urban fallows and $1.65 \%$ are vacant lots.

The development of urban structure is possible on the residential, public amenities, and industrial estate green space, which is evenly spaced in all urban zones of the town, but especially in the inner city. Places with low-density provide free space for the intensification of urban structure. The green spaces around public amenities comprises "pavilion" buildings of schools and hospitals, as well as solitary building of City Library and supermarkets. They constitute $9.20 \%$ of the size of the actual built-up area, of which the industrial estate green space occupies $5.22 \%$, green spaces around public amenities $2.43 \%$, and residential green space $1.55 \%$. The development sites designed in the masterplan constitute $26.50 \%$ of the size of the actual builtup area, of which $20.71 \%$ is in the suburbs and $5.79 \%$ is in the urban area. (Fig. 2) 


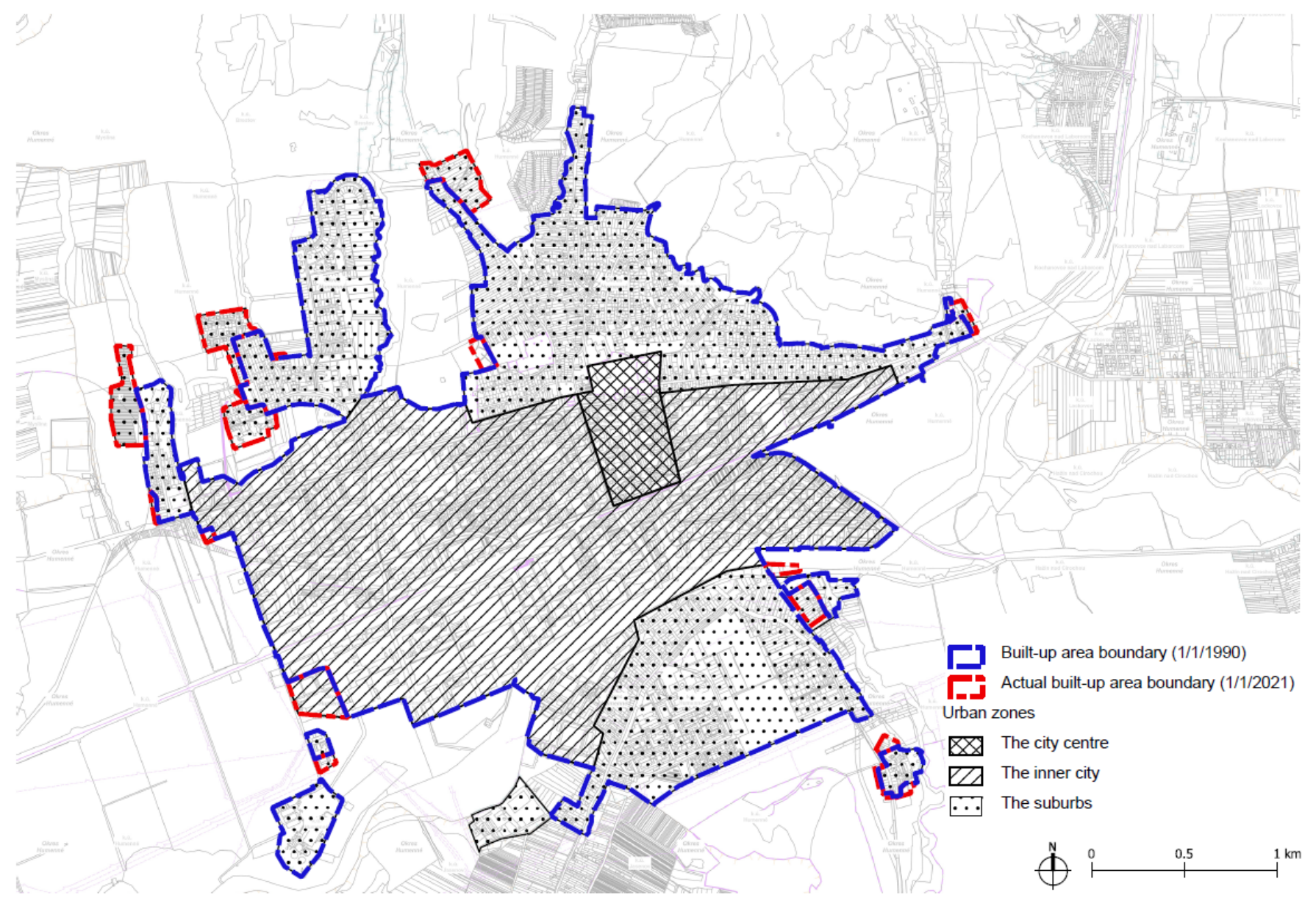

Figure 1: Urban zones in the town of Humenné.

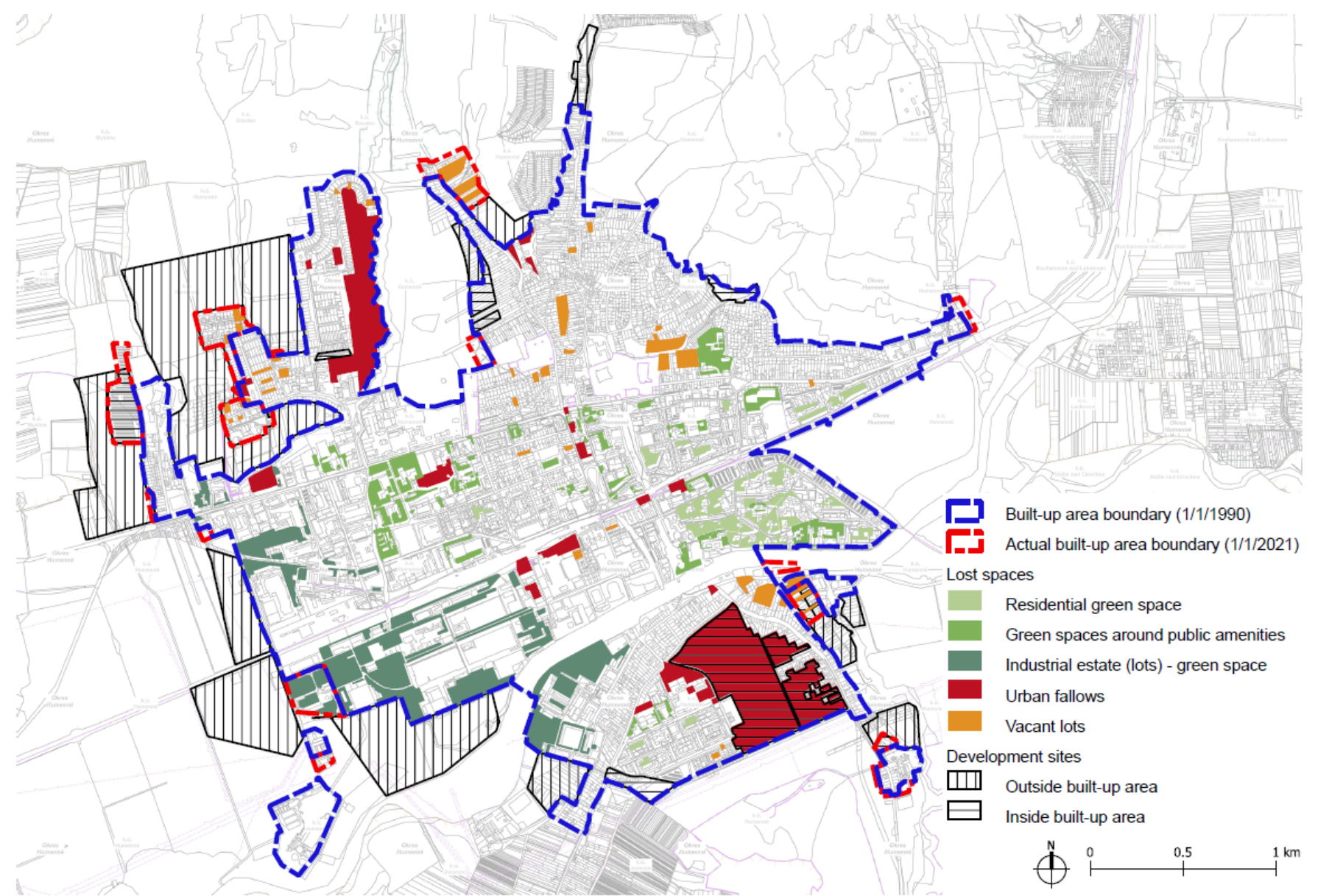

Figure 2: Lost spaces of Humenné in comparison to the development sites as designed in the master plan. Author: Romana Hajduková 


\section{Levice}

The urban structure of Levice is divided into three parts. Likewise Humenné, the continuity of the urban structure is disrupted by the railway which separates only a smaller part of the town, with a predominance of residential housing area, industrial estate, and spacious area of arable land. The eastern part is composed of residential housing areas, smaller housing estates, and "pavilion" buildings of schools. The central part consists of housing estates and public amenities, which are connected to the town centre and Levice Castle. (Fig. 3)

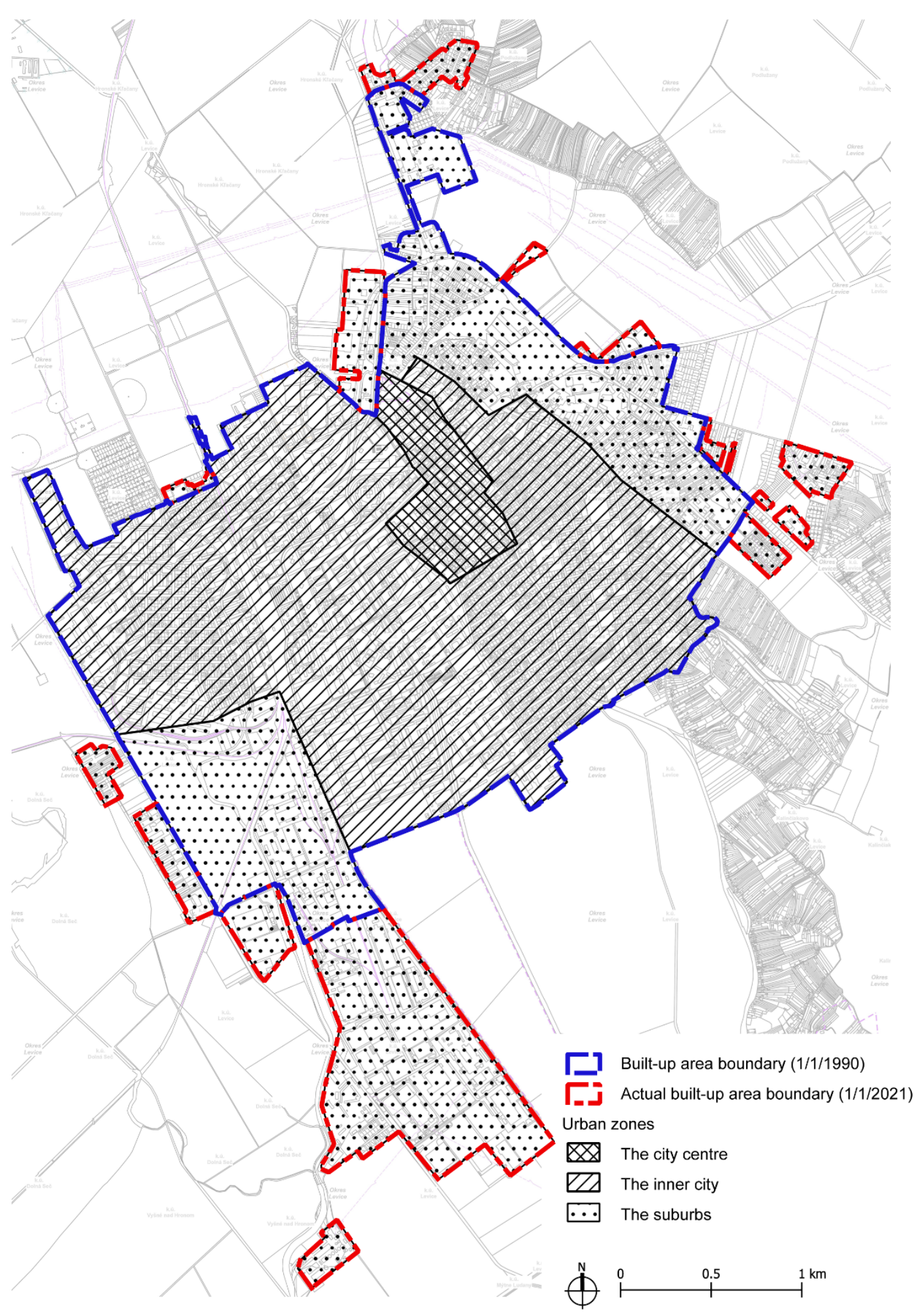

Figure 3: Urban zones in the town of Levice. Author: Romana Hajduková 
Urban fallows within the town are located mostly in the eastern suburbs and in the inner town as part of the housing estate and their buffer zones. In the town centre, there are few urban fallows. Due to the terrain configuration and transport accessibility, the fallows are ideal for merging the urban structure. Though, in the masterplan there are only three of them that are classified as development sites. Vacant lots are evenly located in the suburbs and in the inner town. Residential housing in the suburbs is continuous without any bigger gaps, whose amount increases toward the built-up area boundary. Together, these spaces constitute $6.58 \%$ of the size of the actual built-up area, of which $5.23 \%$ are urban fallows and $1.35 \%$ are vacant lots.

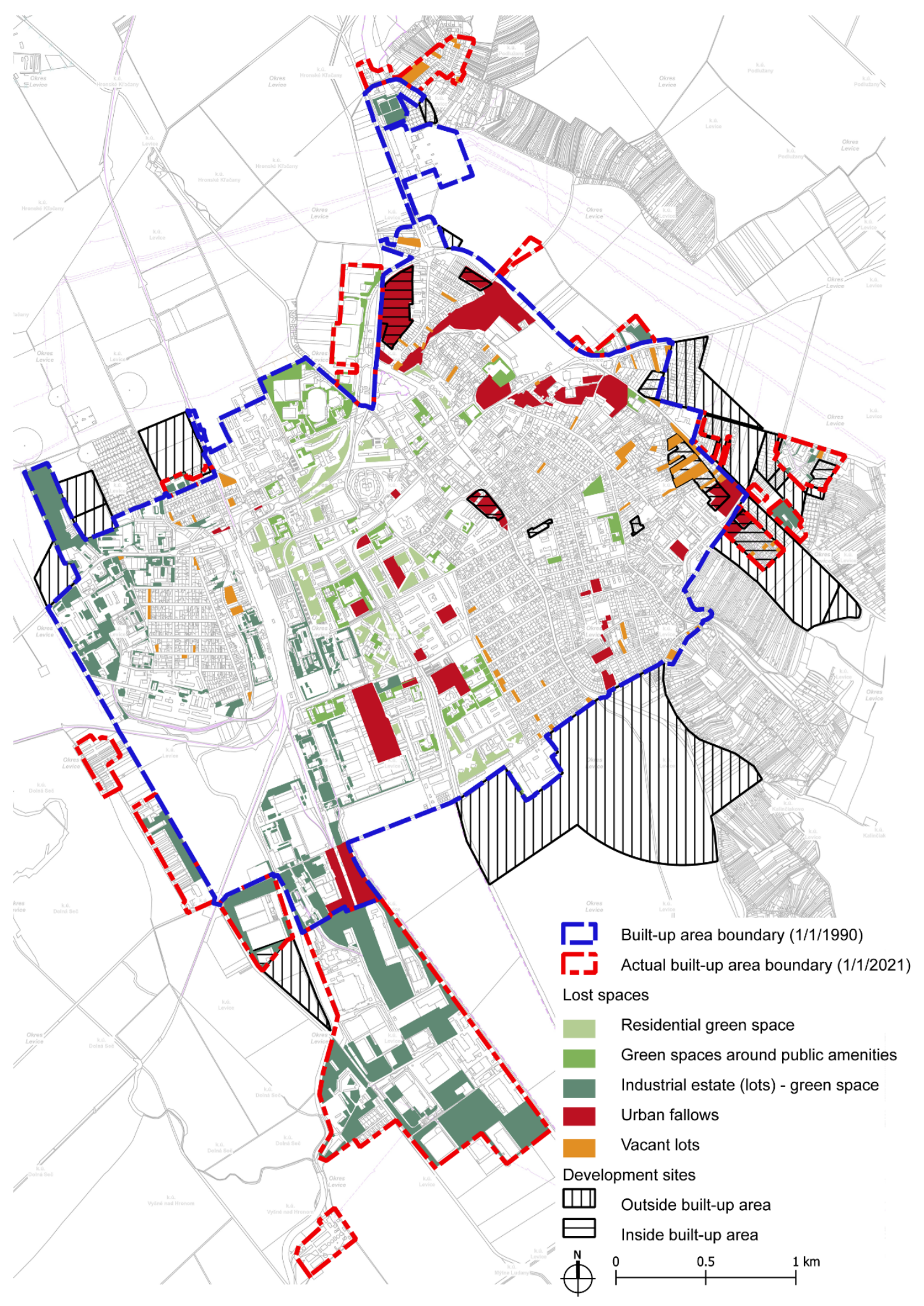

Figure 4: Comparison of lost spaces of Levice and the development sites proposed in the master plan. Author: Romana Hajduková 
A characteristic feature of housing estates in Levice is low density, with large green spaces between apartment buildings, and buffer zones on the site margins. The location of apartment buildings seems non-conceptual, even random. Occasionally, some courtyards of older apartment buildings are used as front gardens. Green spaces around public amenities are located near schools, hospitals, abandoned Culture House Družba, supermarkets and a sports complex in the northern part of the town. Green spaces, especially in the newly built industrial zones, occupy large areas suitable for intensification. Within the town, these areas are in all urban zones. They constitute $13.84 \%$ of the size of the actual built-up area, of which industrial estate green space constitutes $9.70 \%$, green spaces around public amenities $2.40 \%$, and residential green space $1.73 \%$. The development sites proposed in the masterplan constitute $21.45 \%$ of the size of the actual built-up area, of which $18.78 \%$ is in the suburbs and $2.67 \%$ in the inner town. (Fig. 4)

\section{Topol'čany}

The continuity of the urban structure of Topol'čany has been disrupted by two traffic systems. In the north-south direction it is divided by railway tracks, and in the east-west direction it is divided by a road of regional importance. The railway divides the town into two functional zones. In the south-eastern part of the town, there is a centre around which housing estate blocks are concentrated, with an individual residential housing area. The industrial zone is located in the northern tip. The northwestern part comprises a residential housing area and an industrial zone. On a smaller scale, there are also public amenities and military barracks. (Fig. 5)

Urban fallows are in the inner town and the suburbs. Their location is predominantly on the margins, near built-up area boundary, where urban structure begins to crumble and public transport services to the town are less regular. The largest fallows are in contact with the eastern built-up area boundary. Masterplan regulates the southern tip adjacent to the hospital complex. Vacant lots are present on smaller scale and they are scattered evenly in the inner town and the suburbs. Together, these areas comprise $7.30 \%$ of the size of the actual built-up area, of which $6.67 \%$ are urban fallows and $0.63 \%$ are vacant lots.

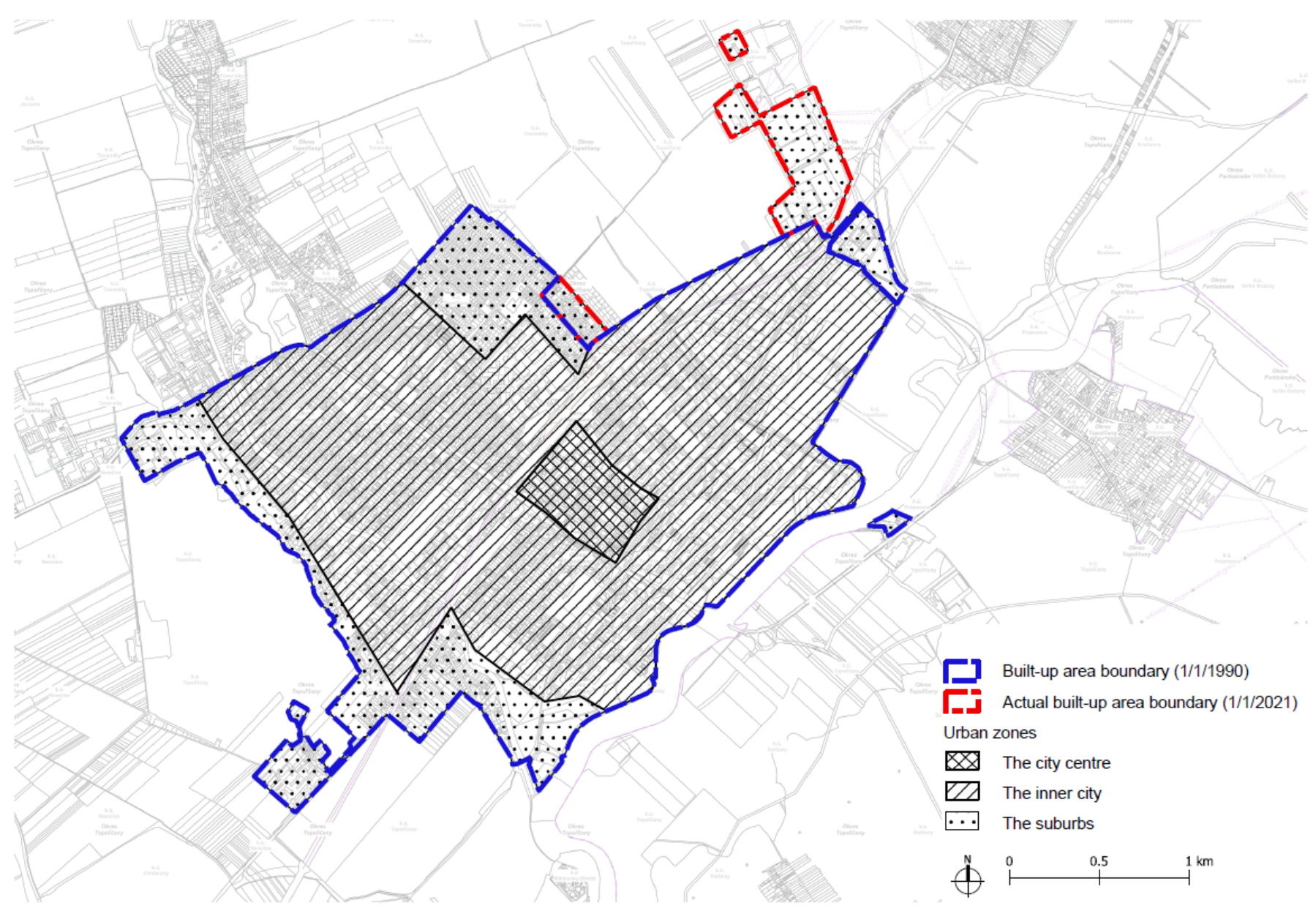

Figure 5: Urban zones in the town of Topolčany. Author: Romana Hajduková 


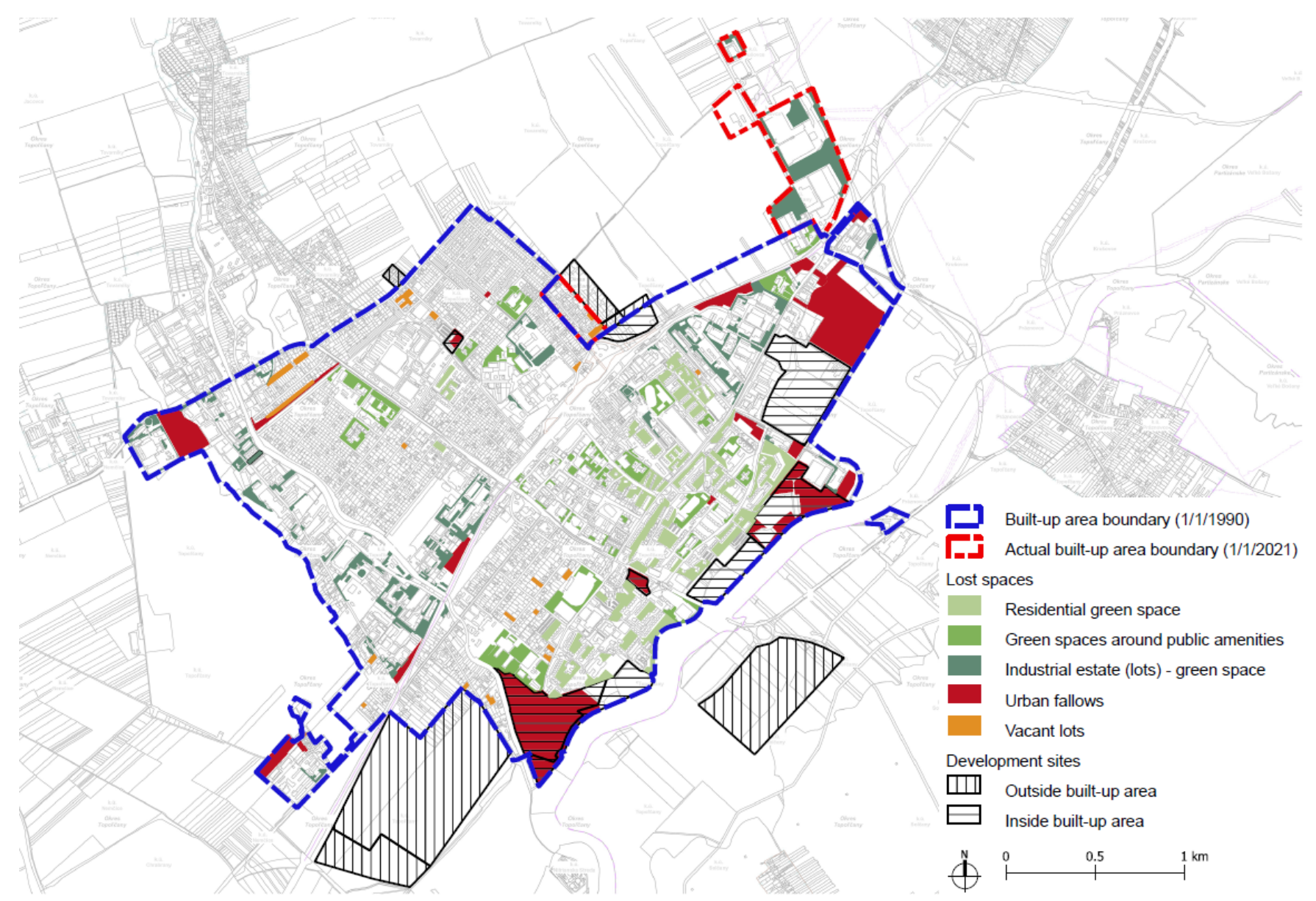

Figure 6: Comparison of lost spaces of Topol'čany with the development sites as proposed in the masterplan. Author: Romana Hajduková

A typical characteristic of housing estates in Topol'čany is lowdensity with unused green areas filling the spaces between apartment buildings and buffer zones. In some cases, courtyards are used as playgrounds; this varies from courtyard to courtyard. "Pavilion" school and hospital buildings are surrounded by greenery that does not serve any purpose and is evenly spaced within the town. Green spaces around public amenities also surround the solitary buildings of the Culture House, the Municipal Cultural Centre, supermarkets and they also fill the remaining unused areas around the football pitch. There are industrial zones with high-density built-up. Within the town, these areas are in all the urban zones, but especially in the inner town. Together they constitute $9.80 \%$ of the size of the actual built-up area, of which industrial estate green space is $3.93 \%$, green spaces around public amenities $2.60 \%$, and residential green space $3.27 \%$. The development sites proposed in the masterplan constitute $20.27 \%$ of the size of the actual built-up area, of which $12.51 \%$ is in the suburbs and $7.76 \%$ is in the urban area. (Fig. 6)

\section{RESULTS}

The first hypothesis tested in this study was whether intensification within the urban area of the towns could be a plausible alternative to the current extensive urban sprawl into the sub- urbs. From the analysed data we can infer that in Humenné the hypothesis was not confirmed and it would not be possible to fully replace the development sites in the suburbs with the lost spaces in the urban zone. Nevertheless, the lost spaces in total constitute more than $3 / 4$ of proposed development sites. That indicates that the spatial potential of Humenné is partly sufficient for the town development in the urban area. Some of the identified urban fallows were proposed as development sites in the masterplan; however, it is not a substitute for the development in the suburbs. In Levice, the hypothesis was confirmed, and it is possible to fully substitute the development sites in the suburbs with the lost spaces identified in the town. The percentage of the size of the actual built-up area is higher by almost $2 \%$ compared to the development sites proposed by the masterplan. This indicates that the spatial potential of Levice is sufficient for its development and it is not necessary to build in the suburbs. The lower percentage of lost spaces compared to Humenné is due to the larger size of the actual built-up area, despite comparable areas of lost spaces. The hypothesis was also confirmed in Topolčany and, likewise Levice, the percentage of the size of actual built-up area is almost $5 \%$ higher compared to the development sites proposed by the masterplan. It is obvious that the spatial potential of Topol'čany is sufficient. (Tab. 2, 3, 4) 
Table 2: Comparison of lost spaces area to the size of actual built-up area.

\begin{tabular}{|c|c|c|c|c|c|c|}
\hline \multirow[b]{2}{*}{ Town } & \multicolumn{6}{|c|}{ Type of lost space } \\
\hline & $\begin{array}{l}\text { Urban fal- } \\
\text { lows }\end{array}$ & Vacant lots & $\begin{array}{c}\text { Residential } \\
\text { green spaces }\end{array}$ & $\begin{array}{l}\text { Green spaces } \\
\text { around public } \\
\text { amenities }\end{array}$ & $\begin{array}{c}\text { Industrial } \\
\text { estate green } \\
\text { spaces }\end{array}$ & Total \\
\hline Humenné & $6.36 \%$ & $1.65 \%$ & $1.55 \%$ & $2.43 \%$ & $5.22 \%$ & $17.21 \%$ \\
\hline Levice & $5.23 \%$ & $1.35 \%$ & $1.73 \%$ & $2.40 \%$ & $9.70 \%$ & $20.41 \%$ \\
\hline Topol'čany & $6.67 \%$ & $0.63 \%$ & $3.27 \%$ & $2.60 \%$ & $3.93 \%$ & $17.10 \%$ \\
\hline
\end{tabular}

Table 3: Development sites proposed by masterplans by location within the town compared to the size of the actual built-up area.

\begin{tabular}{|l|r|r|r|}
\hline \multirow{2}{*}{ Town } & \multicolumn{3}{|c|}{ Development sites } \\
\cline { 2 - 4 } & Outside the built-up area & In the built-up area & Total \\
\hline Humenné & $20.71 \%$ & $5.79 \%$ & $26.50 \%$ \\
\hline Levice & $18.78 \%$ & $2.67 \%$ & $21.45 \%$ \\
\hline Topol'čany & $12.51 \%$ & $7.76 \%$ & $20.27 \%$ \\
\hline
\end{tabular}

Table 4: Development sites area compared to lost spaces area.

\begin{tabular}{|l|r|r|}
\hline Town & Area of development sites outside the built-up area & \multicolumn{1}{|c|}{ Area of lost spaces } \\
\hline Humenné & $20.71 \%$ & $17.21 \%$ \\
\hline Levice & $18.78 \%$ & $20.41 \%$ \\
\hline Topol'čany & $12.51 \%$ & $17.10 \%$ \\
\hline
\end{tabular}

Author: Romana Hajduková

The second hypothesis was to determine whether most lost spaces are in the town centres. It was not confirmed in any of the towns, because the location of lost spaces is often evenly spaced. In all of the towns, the largest lost spaces were on the outskirts of the town in industrial areas and zones where compact urban structure begins to crumble.

\section{DISCUSSION}

The first hypothesis was not confirmed only for the town of Humenné. The inability to confirm the hypothesis can be caused by a multitude of factors concerning both the town itself and its masterplan, such as the time of masterplan elaboration. Methods of elaboration of masterplans in Slovakia are inconsistent and depend in many aspects on the urban planners and requirements of municipal authorities. The masterplans and their updates, which we used in this study, were elaborated in the years of 2006, 2008, 2014 (Humenné), 2005-2013, 20162017, 2019-2020 (Levice) and 2007-2008, 2010, 2012, 2015, 2018 (Topol'čany). At the time of elaboration of masterplans, greater economic growth and the associated urban development were anticipated. A characteristic feature of the towns in the study is the declining population, the obtained data were analysed and compared regardless of their economic and employment potential. During masterplans elaboration, emphasis has rarely been placed on the vacant land lots suitable for development for "recycling" in the urban area of towns. Such land lots are considered stabilized areas for which there is no possibility of further development until the next update of the masterplan. The potential for renewal differs depending on publicprivate spatial division, where vacant lots are owned by private sector, but housing estates are owned by the public sector. Finally, the extent of development sites is also influenced by the inaction of local authorities, which do not account for the requirements of investors in the approval process. Confirmation of the hypothesis in the towns of Levice and Topol'čany gives ground to new research questions. Is the continuity of the urban structure of towns disrupted by the vacant land lots or is the extent of proposed development sites underestimated? And do stagnant and declining towns need such large development sites?

Based on the fact that the second hypothesis has not been confirmed, we can assume that spatial potential is evenly spaced within the town. We can infer that the lost spaces are often residual spaces after the designing process, or spaces never redeveloped. This fact is also important with respect to the possible addition of the green infrastructure on some of the vacant land lots. 


\section{CONCLUSION}

Climate change and its effects on the towns and our lives are irreversible. The role of urban planners is to address these issues and the resulting challenges. As the study showed, medium-sized Slovak towns seem to have greater spatial potential, which can be an impulse for urban renewal, with focus on achieving the optimum rate of compactness and continuity of existing urban structure and on creating a new one.

It is crucial to realize that cities and towns are living organisms, continually evolving, and it is neither possible nor desirable to reach the full density of the urban structure. A certain form of feeling lost in space gives cities identity and space for growth, but the excess of lost spaces shatters the city into disorganized chaos. The question arises as to what percentage of the lost spaces is ideal or universal for all existing cities and towns, and does it exist at all? Exploring and searching for the good rate between built-up area and open space is the key to urban structure renewal. And, above all, the urban renewal of cities is a never-ending process, and therefore it is crucial to keep in mind the constant need for evaluation of urban structures.

\section{REFERENCES:}

[1] Jacobs, J. (2013) "Smrt a život amerických velkoměst", MOX NOX, Dolní Kounice, Czech Republic.

[2] Glaeser, E. (2019) "Triumf mesta”, Premedia. Bratislava, Slovakia.

[3] Trancik, R. (2017) “Co je ztracený prostor?”, In: I. Fialová

(ed.) Architektura a současné mesto: texty o moderní a

současné architektuře VI, Zlatý rez, Praha, Czech Republic, pp. 15-28.

[4] Lynch K., Carr S. (1979) "Open Space: Freedom and Control", In: City Sense and City Design: Writings and Projects of Kevin Lynch, MIT, Cambridge, United Kingdom, pp. 413-417. [5] de Solà-Morales, I. (1995) "Terrain Vague", In: Anyplace, MA: MIT Press, Cambridge, United Kingdom, pp. 118 - 123.

[6] Háblová A. B. (2019) "Nemísta měst. Opomíjená, pomíjivá a míjená místa měst", Host, Brno, Czech Republic.

[7] Augé, M. (1995) "Non-places: an introduction to supermodernity", Verso, New York - London, USA, United Kingdom.

[8] Augé, M. (1999) "Antropologie současných světů",

Atlantis, Brno, Czech Republic.

[9] Jonas M., Rahmann H. (2014) "Intervention, Transgression, and Appropriation", In: Tokyo Void: possibilities in absence, Jovis, Berlin, Germany, pp. 36-81.

[10] Doron, G. (2007) “...badlands, blank space, border vacuums, brown fields, conceptual Nevada, Dead Zones..." Field: a free journal for architecture, 1(1), pp. 10-23. Available at: http://field-journal.org/wp-content/uploads/2016/07/g-doron.pdf [Accessed: 13 March 2021]

[11] Larsen, J. L. (2004) „Vague spaces - recognising other urbanities in the city", Microeconomics exhibition contribution. [online] Available at:

https://supertankerinfo.files.wordpress.com/2010/08/jan-

lilliendahl-larsen-supertanker-vague-spaces-recognizing-otherurbanities-in-the-city.pdf [Accessed: 15 March 2021]

[12] Jacobs, J. (2012) "Ekonomie měst", MOX NOX, Dolní Kounice, Czech Republic.

[13] Alexy, T. (1982) "Rekonštrukcia sídiel", Slovenská vysoká škola technická v Bratislave, Bratislava, Slovakia.
[14] Alexy, T. (1999) "Vývoj a premena urbanistickej štruktúry", Slovenská vysoká škola technická v Bratislave, Bratislava, Slovakia.

[15] The term was firstly used in the 1970s in New York. Painter Liz Christy with friends cleaned up a vacant land plot and began to plant trees and flower beds there.

[16] Trancik, R. (1986) "Finding lost space", Van Nostrand Reinhold Company, New York, USA.

[17] Hyra, D. (2014) "The Back-To-The-City Movement: Neighbourhood Redevelopment and Processes of Political and Cultural Displacement", Urban Studies Journal Foundation, 52(10), pp. 1-21. https://doi.org/10.1177/0042098014539403 [DOI]

[18] Kaliská, D. (2012) "Diferenciácia a hodnotenie vybraných slovenských sídiel”, In: Vitková, L'., Kováč, B. (eds.) Intenzita využitia územia - vybrané otázky (Land use intensity - selected issues), Nakladatel'stvo STU, Bratislava, Slovakia, pp. 81-125. [19] Website "Geoportal GKÚ". [online] Available at: https://www.geoportal.sk/sk/sluzby/mapove-sluzby/wms/ [Accessed: 1 March 2021]

[20] Vaishar, A., Zdráhalová, J. (2003) "Problems of European inner cities and their residential environments", Moravian geographical reports, 11(2), pp. 24-35. [online] Available at: http://www.geonika.cz/EN/research/ENMgr/MGR_2003_02.pdf [Accessed: 19 April 2021]

[21] Sopirová, A. (2014) "Sídla v zázemí miest: Slovensko v priestore po dvadsiatich rokoch" (Settlements in the vicinity of towns: Spatial changes in Slovakia over the past twenty years), Architecture papers of the faculty of architecture and design STU, 2014(3), pp. 46-55. (in Slovak language) [online] Available at: https://alfa.stuba.sk/wpcontent/uploads/2020/05/03 2014 Sopirova.pdf [Accessed: 19 April 2021] 